\title{
IMPLEMENTASI PENYELENGGARAAN KETERTIBAN UMUM DAN KETENTRAMAN MASYARAKAT PADA DINAS SATUAN POLISI PAMONG PRAJA DAN PEMADAM KEBAKARAN KABUPATEN SIDENRENG RAPPANG
}

\author{
1)Marwah, 2)Erfina, ${ }^{3)}$ Hariyanti Hamid \\ Fakultas IImu Sosial dan IImu Politik Universitas Muhammadiyah Sidenreng Rappang \\ Marwahl@gmail.com
}

\begin{abstract}
Abstrak
Penelitian ini bertujuan untuk mengetahui implementasi kebijakan Penegakan Peraturan Daerah No. 8 Tahun 2012 tentang penyelenggaraan ketertiban umum dan ketentraman masyarakat pada Dinas Satuan Polisi Pamong Praja dan Pemadam Kebakaran Kabupaten Sidenreng Rappang dan faktor yang menghambat implementasi kebijakan Penegakan Peraturan Daerah No. 8 Tahun 2012 tentang penyelenggaraan ketertiban umum dan ketentraman masyarakat pada Dinas Satuan Polisi Pamong Praja dan Pemadam Kebakaran Kabupaten Sidenreng Rappang dengan menggunakan penelitian deskriftif kualitatif. Hasil penelitian menunjukkan bahwa implementasi kebijakan Penegakan Peraturan Daerah No. 8 Tahun 2012 tentang penyelenggaraan ketertiban umum dan ketentraman masyarakat pada Dinas Satuan Polisi Pamong Praja dan Pemadam Kebakaran Kabupaten Sidenreng Rappang sudah terlasana dengan baik dilihat dari aspek standard dan sasaran kebijakan, sumber daya, komunikasi antar organisasi dan penguatan aktivitas, karateristik agen pelaksana, kondisi sosial ekonomi dan politik dan disposisi implementor. Sedangkan faktor yang menghambat implementasi kebijakan Penegakan Peraturan Daerah No. 8 Tahun 2012 tentang penyelenggaraan ketertiban umum dan ketentraman masyarakat pada Dinas Satuan Polisi Pamong Praja dan Pemadam Kebakaran Kabupaten Sidenreng Rappang antara lain secara kelembagaan, sumber daya manusia, jaringan kerja dan lingkungan yang belum kondusif.
\end{abstract}

Kata Kunci : Implementasi Kebijakan, Peraturan Daerah

\begin{abstract}
This study aims to determine the implementation of the Regional Regulation No. Enforcement Policy. 8 of 2012 concerning the implementation of public order and public order at the Sidenreng Rappang District Police Service Unit and Fire Service and factors that hinder the implementation of the policy on the Enforcement of Regional Regulation No. 8 of 2012 concerning the implementation of public order and public order at the Service of the Civil Service Police Unit and the Fire Department of Sidenreng Rappang Regency using qualitative descriptive research. The results showed that the implementation of the Local Regulation No. Enforcement Policy. 8 of 2012 concerning the implementation of public order and public order at the Sidenreng Rappang District Police and Fire Service Offices have been well implemented, seen from the aspects of standards and policy targets, resources, communication between organizations and strengthening activities, characteristics of implementing agencies, social conditions. economics and politics and the disposition of implementors. While the factors that hinder the implementation of the policy on the Enforcement of Regional Regulation No. 8 of 2012 concerning the implementation of public order and public order at the Service of the Civil Service Police Unit and the Fire Service of Sidenreng Rappang Regency, among others, institutionally, human resources, work networks and an environment that is not yet conducive.
\end{abstract}

Keywords: Policy Implementation, Regional Regulations

PRAJA | Volume 7 | Nomor 2 | Edisi Juni 2019 


\section{A. PENDAHULUAN}

Peran Pedagang Kaki Lima (PKL) sebagai aset ekonomi serta kenyataan kegiatannya yang sering menimbulkan masalah lingkungan hidup terutama kemacetan lalu lintas dan kegiatan penertiban/penggusuran yang dilakukan oleh pemerintah kabupaten Sidenreng Rappang. Berangkat dari fenomena diatas, berdasarkan Peraturan Daerah No. 8 Tahun 2012 tentang penyelenggaraan ketertiban umum dan ketentraman masyarakat Pasal 21 tentang pemakaian tempat berjualan di atas, ternyata masih banyak pedagang yang tidak mematuhi peraturan yang sudah berlaku, dan kurangnya perhatian pemerintah terhadap pemberdayaan sektor informal khususnya Pedagang Kaki Lima (PKL).

Satuan Polisi Pamong Praja (Satpol PP) memiliki kedudukan dan peranan yang cukup luas sebagai salah satu perangkat dan aparatur pemerintah daerah. Berdasarkan Pasal 255 Undang-Undang Nomor 23 Tahun 2014 tentang Pemerintahan Daerah diketahui bahwa Satpol PP bertugas membantu kepala daerah dalam menegakkan Perda dan penyelenggaraan ketertiban umum dan ketentraman masyarakat serta perlindungan masyarakat. Berdasarkan Pasal 6 Peraturan Pemerintah Nomor 6 Tahun 2010 tentang Satuan Polisi Pamong Praja diketahui bahwa secara spesifik Satpol PP memiliki kewenangan, melakukan tindakan penertiban nonyustisial terhadap warga masyarakat, aparatur, atau badan hukum yang melakukan pelanggaran atas Perda dan/atau peraturan kepala daerah; menindak warga masyarakat, aparatur, atau badan hukum yang mengganggu ketertiban umum dan ketentraman masyarakat; fasilitasi dan pemberdayaan kapasitas penyelenggaraan perlindungan masyarakat; melakukan tindakan penyelidikan terhadap warga masyarakat, aparatur, atau badan hukum yang diduga melakukan pelanggaran atas Perda dan/atau peraturan kepala daerah; dan melakukan tindakan administratif terhadap warga masyarakat, aparatur, atau badan hukum yang melakukan pelanggaran atas Perda dan/atau peraturan kepala daerah.

Peraturan Daerah yang dibentuk mencakup aspek yang cukup luas dan beragam, mulai dari regulasi yang mengatur organisasi dan tata kerja instansi pemerintah sendiri hingga aspek umum dan sosial lainnya. Hal ini menjadikan peranan dan
p-ISSN 2302-6960 e-ISSN 2716-165X

tanggung jawab Satpol PP semakin bertambah. Berdasarkan hal tersebut, menurut Penulis dan sebagai salah satu referensi proses penyelarasan antara tugas dan kewenangan Satpol PP sebagai penegak peraturan daerah maka memerlukan perhatian.

Berangkat dari fenomena dan tata pelaksanaan penegakan peraturan daerah oleh Satpol PP Kabupaten Sidrap, berdasarkan observasi penulis dapat digambarkan kelemahan implementasinya dilapangan khusunya Peraturan daerah No. 8 Tahun 2012 tentang penyelenggaraan ketertiban umum dan ketentraman masyarakat, diakibatkan minimnya sosialisasi di masyarakat, kurang partisipasi masyarakat dalam implmentasi perda, masih belum terjalinnya kerjasama berlanjut antara penegak hukum yang lain. Hal tersebut pada prinsipnya memerlukan tata kelola kerja yang disusun di implementasikan secara profesional dan akuntabel, sebab akar masalah yang ditimbulkan pada prinsipnya berawal dari minimnya rangkaian kerja yang dibangun sehingga tahapan-tahapan penegakan belum secara maksimal.

Penyelenggaraan ketertiban umum dan ketentraman masyarakat dimaksudkan untuk mewujudkan tata kehidupan masyarakat Sidenreng Rappang yang tertib, tentram, nyaman, bersih dan indah sehingga diperlukan adanya pengaturan bidang ketertiban umum yang mampu melindungi warga masyarakat, sarana dan prasarana. Penyelenggaraan Ketertiban umum dan ketentraman masyarakat bertujuan untuk pencapaian kondisi yang kondusif bagi seluruh aspek kehidupan masyarakat dan diharapkan implementasi terhadap penyelenggaraan ketertiban umum dan ketentraman masyarakat dapat diterapkan secara optimal guna menciptakan ketentraman, ketertiban, dan kenyamanan.

Perspektif penegakan perda, anggota Satpol PP dituntut menunjukkan kinerjanya dengan melakukan aktivitas kerja dalam menata dan melakukan ketertiban umum kepada masyarakat terutama masalah aktivitas usaha masyarakat yang sering disebut pedagang kaki lima, miras dan perjudian dan lain sebagainya, hal ini membutuhkan penegakan karena masih banyak masyarakat menempati usaha yang tidak diperuntukkan bagi usaha seperti trotoar, badan jalan, taman dan lapangan. 
Kinerja Satpol PP harus mampu melakukan penegakan tersebut dengan menunjukkan sikap disiplin, menyelesaikan tugas sesuai aturan serta menegakkan aturan dengan pendekatan lebih inovatif dan kreatif sehingga tidak mudah menimbulkan benturan dilapangan.

Berdasarkan uraian di atas, maka penulis merasa terdorong untuk mengkaji dan meneliti lebih lanjut mengenai permasalahan implementasi kebijakan penegakan Perda yang telah disusun pemerintah dan anggota legislatif, sehingga diangkat suatu penelitian sederhana dengan judul Implementasi Kebijakan Penegakan Peraturan Daerah No. 8 Tahun 2012 tentang Penyelenggaraan Ketertiban Umum dan Ketentraman Masyarakat pada Dinas Satuan Polisi Pamong Praja dan Pemadam Kebakaran Kabupaten Sidenreng Rappang maka tujuan penelitian ini adalah untuk mengetahui implementasi kebijakan Penegakan Peraturan Daerah No. 8 Tahun 2012 tentang penyelenggaraan ketertiban umum dan ketentraman masyarakat pada Dinas Satuan Polisi Pamong Praja dan Pemadam Kebakaran Kabupaten Sidenreng Rappang dan untuk mengetahui faktor yang menghambat implementasi kebijakan Penegakan Peraturan Daerah No. 8 Tahun 2012 tentang penyelenggaraan ketertiban umum dan ketentraman masyarakat pada Dinas Satuan Polisi Pamong Praja dan Pemadam Kebakaran Kabupaten Sidenreng Rappang.

Implementasi dalam arti harfiah adalah pelaksanaan. Untuk lebih jelasnya, implementasi dapat diartikan sebagai suatu usaha atau kegiatan berkesimbungan yang dilakukan untuk mewujudkan rencana atau program menjadi kenyataan. Bernardine R. Wijaya \& Susilo Supardo dalam Harbani Pasolog (2014:57) mengatakan bahww implementasi adalah proses mentransformasikan suatu rencana ke dalam praktek. Secara garis besar implementasi dapat diartikan sebagai setiap kegiatan yang dilakukan menurut rencana untuk mencapai tujuan yang telah ditentukan. Menurut Van meter dan Carl E. Horn dalam AG. Subarsono (2010:99), ada enam variabel yang mempengaruhi kinerja implementasi, yakni :

1. Standar dan sasaran kebijakan. Standar dan sasaran kebijakan harus jelas dan terukur sehingga dapat direalisir. Apabila
p-ISSN 2302-6960

e-ISSN 2716-165X

standar dan sasaran kebijakan kabur, maka akan terjadi multiinterpretasi dan mudah menimbulkan konflik antar agen implementasi

2. Sumber daya. Implementasi kebijakan perlu dukungan sumberdaya, baik sumberdaya manusia (human resources) maupun sumberdaya non-manusia ( nonhuman resourse)

3. Hubungan Antar Organisasi. Dalam bentuk banyak program, implementasi sebuah program perlu dukungan dan koordinasi dengan intansi lain. Untuk itu diperlukan koordinasi dan kerjasama antar instansi bagi keberhasilan suatu program.

4. Karakteristik agen pelaksana. Yang dimaksud kerakteristik agen pelaksana adalah mencakup struktur birokrasi, norma-norma, dan polapola hubungan yang terjadi dalam birokrasi, yang semuanya itu akan memengaruhi implementasi suatu program.

5. Kondisi sosial, politik, dan ekonnomi. Veriabel ini mencakup sumberdaya ekonomi lingkungan yang dapat mendukung keberhasilan implementasi kebijakan.

6. Disposisi implementor atau sikap pelaksana. Sikap mereka itu dipengaruhi oleh pandangannya terhadap suatu kebijakan dan cara melihat pengaruh organisasinya dan kepentingankepentingan pribadinya. Disposisi implementasi kebijakan diawali penyaringan (befiltered) lebih dahulu melalui persepsi dari pelaksanaan (implementors) dalam batas mana kebijakan itu dilaksanakan. Terdapat tiga macam elemen respon yang dapat mempengaruhi kemampuan dan kemauannya untuk melaksanakan suatu kebijakan, antara lain terdiri dari pertama, pengetahuan (cognition), pemahaman dan pendalaman (comprehension and understanding) terhadap kebijakan, kedua, arah respon mereka apakah menerima, netral atau menolak (acceptance, neutrality, and rejection), dan ketiga, intensitas terhadap kebijakan.

Rangka mewujudkan tata kehidupan Kabupaten Sidenreng Rappang yang tertib, tenteram, nyaman, bersih dan indah, diperlukan adanya pengaturan di bidang ketertiban umumyang mampu melindungi warga dan prasarana pemerintah daerah 
beserta kelengkapannya. Hal ini dapat dilihat pada :

\section{Pasal 21}

1. Bupati menunjuk/menetapkan bagianbagian jalan/trotoar dan tempat-tempat kepentingan umum lainnya sebagai tempat usaha pedagang kaki lima

2. Setiap orang atau badan dilarang berdagang, berusaha di bagian jalan/ trotoar, halte dan tempat-tempat untuk kepentingan umum lainnya di luar ketentuan sebagaiman dimaksud pada ayat (1)

3. Sertiap orang dilarang membeli barang dagangan pedagang kaki lima sebagaimana dimaksud pada ayat (2)

Pasal 22

1. Setiap pedagang kaki lima yang menggunakan tempat berdagang sebagaimana dimaksud dalam Pasal 21 ayat (1) harus bertanggungjawab terhadap ketertiban, kebersihan dan menjaga kesehatan lingkungan serta keindahan di sekitar tempat berdagang yang bersangkutan

2. Ketentuan lebih lanjut mengenai tata cara dan prosedur penetapan tempat usaha tertentu sebagaimana dimaksud dalam Pasal 21 ayat (1) diatur dengan Peraturan Bupati.

Bukti-bukti tersebut menggambarkan bahwa pekerjaan sebagai PKL merupakan salah satu pekerjaan yang relatif tidak terpengaruh krisis ekonomi karena dampak krisis ekonomi tidak secara nyata dirasakan oleh pedagang kaki lima. Dalam hal ini PKL mampu bertahan hidup dalam berbagai kondisi, sekalipun kondisi krisis ekonomi.

1. Pembinaan Pedagang Kaki Lima (PKL). Pembinaan dilakukan untuk meningkatkan sikap serta keterampilan dengan membawa harapan agar mampu mengankat suatu nasib dari segala obyek yang dibina. Tujuan pembinaan dilatih agar dapat meningkastkan kemasmpuan serta pengembangasn supaya dapat manfaatkan penuh dalam bidang hidup kerja mereka.

2. Arah Pembinaan. PKL mencari suatu solusi yang baik serta bijaksana, karena pemusnahan tanpa memberi jalan keluar dengan memberi tempat yang memenuhi syarat, sama saja dengan mematikan tumbuhnya ekonomi kerakyatan, yang notabene sumber hidup masyarakat bawah. Sektor ini membutuhkan perhatian
p-ISSN 2302-6960

e-ISSN 2716-165X

yang lebih baik lagi dari pihak pemerintah. Oleh karena itu, jalan yang terbaik untuk menangani sektor ini adalah melalui pembinaan.

\section{B. METODE PENELITIAN}

Penelitian ini dilaksanakan pada Satuan Polisi Pamong Praja Kabupaten Sidenreng Rappang yang beralamat di Jalan Harapan Baru Kompleks SKPD Blok B No. 12 Kabupaten Sidenreng Rappang, dengan penelitian lapangan yakni dengan melakukan pengumpulan data penelitian secara langsung pada obyek dengan maksud diperoleh data lapangan yang dijamin kebenaran dan kesahihannya, dalam bentuk wawancara, untuk itu dilakukan penelitian sejumlah Staf dalam lingkup Satpol PP Kabupaten Sidenreng Rappang dan pedagang Kaki Lima. Tipe yang digunakan dalam penelitian ini adalah pendekatan deskriptif, yaitu yang menggambarkan secara umum tentang masalah yang diteliti. Penelitian ini menggunakan jenis penelitian deskriptif dengan pendekatan kualitatif, yakni suatu bentuk penelitian yang memberikan gambaran mengenai objek yang diamati atau fokus penelitian. Pengumpulan data, menggunakan cara observasi, wawancara dan dokumentasi.

\section{HASIL DAN PEMBAHASAN}

Setelah melakukan penelitian ke lokasi penelitian baik melalui wawancara maupun observasi lapangan, peneliti mendapatkan data-data yang kompleks. Namun setelah melakukan proses reduksi data maka didapatkan data-data yang dibutuhkan dalam penelitian implementasi kebijakan penegakan Peraturan Daerah No. 8 Tahun 2012 tentang Penyelenggaraan Ketertiban Umum dan Ketentraman Masyarakat pada Dinas Satuan Polisi Pamong Praja dan Pemadam Kebakaran Kabupaten Sidenreng Rappang. Data-data tersebut akan dipaparkan yang terdiri dari:

1. Standar dan Sasaran Kebijakan

Standar operasional prosedur merupakan suatu alat organisasi untuk menjabarkan bagaimana penanganan dalam mengatasi masalah penertiban PKL ke dalam terminologi operasional sehingga semua orang yang terlibat dalam permasalahan tersebut akan terikat dalam suatu sistem, baik PKL dan satpol PP, akan bertanggung 
jawab dalam melaksanakan tugas dan perannya masing-masing.

SOP adalah suatu set instruksi (perintah kerja) terperinci dan tertulis yang harus diikuti demi mencapai keseragaman dalam menjalankan proses, prosedur ini adalah standar yang sangat rinci dari kegiatan yang dilakukan oleh pelaksana pada masing-masing divisi dan jabatan dan dibuat sebagai pedoman kerja. Bagi Satuan Polisi Pamong Praja memahami arti penting keberadaan SOP bagi instansi mereka, sangat meyakini bahwa SOP akan memberikan manfaat yang sangat banyak.

Adanya standar yang jelas harus dipenuhi dan dimiliki oleh para petugas dalam melaksanakan tugas yang diemban sehingga kesalahan-kesalahan yang terjadi pada saat menjalankan tugas dapat terminimalisir.Para sasaran kebijakan pun seyogyanya tidak kehilangan hak-hak mereka berdasarkan Standar yang digunakan.Demikian penting suatu SOP sehinga dapat mengurangi resiko-resiko yang dapat terjadi dan merugikan suatu organisasi khususnya Satuan Polisi Pamong Praja Kabupaten Sidenreng Rappang .Tidak hanya komunikasi, sumber daya, disposisi, maka struktur birokrasi juga sangat menentukan efektifnya pelaksanaan kebijakan tersebut.

Berdasarkan pendapat di atas penulis menarik kesimpulan bahwa aspek ini telah berjalan diaman Satpol PP Kabupaten Sidenreng Rappang dalam mengatur PKL yang ada di Kabupaten Sidenreng Rappang telah memiliki standar yang jelas dan telah melaksanakannya sesuai dengan aturan tersebut, namun demikian berdasarkan observasi penulis memang dalam menjalankan SOP yang ada pada saat penertiban di lapangan yang telah dilaporkan oleh masyarakat, masih memiliki hambatan dan dukungan oleh sikap Masyarakat Kabupaten Sidenreng Rappang terhadap fenomena keberadaan PKL dapat dibagi dalam 3 kategori, yaitu: 1) Masyarakat yang menginginkan PKL tetap ada dikarenakan meraka membutuhkannya dikarenakan lingkungan sekitar tidak menyediakan fasilitas berjualan dan akses berjaualan yang begitu jauh, 2) Masyarakat yang menentang PKL atas dasar kebersihan lingkungan 3) Masyarakat yang abstain atau tidak mau tahu dengan dampak PKL itu sendiri. Oleh karena itu menurut hemat penulis pentingnya SOP tersebut sekiranya dapat lebih dimutakhirkan kembali tidak hanya memuat cara-cara penanggulangan dari sasaran kebijakan tetapi seyogyanya juga memuat seluruh aspek yang dapat mempengaruhi dalam penertiban PKL itu sendiri.

\section{Sumber Daya}

Berdasarkan jumlah Satpol PP/ personil berdasarkan Data penelitian telah memadai dan kualifikasi pendidikan adalah merupakan hal yang sangat berpengaruh terhadap kemampuan kerja seseorang. Demikian pula halnya dalam rangka peningkatan kemampuan aparatur dalam melaksanakan tugas, karena dengan latar belakang pendidikan yang memadai mereka dapat menyesuaikan kecakapan dan pengetahuan yang dimiliki dengan tugas yang harus dilaksanakan.

Kondisi yang demikian ini walaupun beberapa pegawai telah memiliki kualifikasi pedidikan yang baik tentu perlu pula penambahan keahlian dari pemerintah daerah khususnya bagi yang berpendidikan SMA untuk mendapat pendidikan tambahan melalui pendidikan dan pelatihan atau kursus-kursus yang diprogramkan sehingga diharapkan anggota satpol PP tadi dapat menerapkannya dalam rangka penertiban sasaran kebijakan (PKL). Segi sumber daya manusia dari tingkat kualifikasi dan jumlah personil telah memadai dimana untuk pegawai lapangan telah memiliki ratusan personil, hal demikian penulis menganggap wajar dikarenakan demi melaksanakan penertiban sejumlah perda yang ada di Kabupaten Sidenreng Rappang tidak hanya perda penertiban PKL. Namun dalam pemberian pelatihan yang ada pemerintah daerah seyogyanya dapat lebih meningkatkannya kembali mengingat jumlah personil Satuan Polisi Pamong Praja dan Pemadam Kebakaran Kabupaten Sidenreng Rappang cukup memadai.

Kantor Dinas Satuan Polisi Pamong Praja dan Pemadam Kebakaran Kabupaten Sidenreng Rappang memiliki jumlah aparat penegak perda sebanyak 150 Orang Pegawai, namun tidak sebanding dengan volume kendaraan yang tersedia, dimana fasilitas kendaraan roda 4 yang ada hanya 2 kendaraan saja, menurut hemat penulis kekurangan tersebut akan berpengaruh terhadap keberhasilan penertiban kebijakan PKL yang ada di kawasan padat PKL seperti Pasar dan pelataran Ganggawa dan kawasan lainnya secara maksimal. 
Sarana penunjang yang dimiliki Kantor satpol PP belum sesuai apa yang diharapkan dan masih ada beberapa yang harus ditambahkan serta ditingkatkan jumlah dan kualitasnya, diantaranya sarana kendaraan serta beberapa alat penunjang lainnya seperti kendaraan oprasional mengingat polisi pamong praja juga melaksanakan penertiban perda lainnya bukan hanya perda penertiban PKL sehingga dapat dikatakan belum sepenuhnya tercapai sesuai apa yang diharapkan.

3. Komunikasi Antar Organisasi dan Penguatan Aktifitas

Analisis implementasi Peraturan Daerah Kabupaten Sidenreng Rappang Nomor 8 Tahun 2012 Tentang Penyelenggaraan Ketertiban Umum dan Ketentraman Masyarakat ini komunikasi terbagi menjadi dua yaitu komunikasi internal dan juga komunikasi internal :

a. Komunikasi Internal Pelaksanaan penertiban PKL di Kabupaten Sidenreng Rappang dilakukan di berbagai tempat seperti jalan protokol dan pasar. Menanggapi hal tersebut, Satpol PP Kabupaten Sidenreng Rappang sebenarnya telah melakukan beberapa kali penertiban namun hal demikian belum efektif dikarenakan faktor keterbatasan komunikasi yang diberikaan kepada PKL dan kendala PKL itu sendiri yang tidak mengindahkan pengaturan tersebut.

b. Komunikasi Eksternal. Pada sisi komunikasi ini, penulis beranggapan ada peluang yang dapat dimanfaatkan yaitu pemanfaatan komunikasi berupa koordinasi secara intens yang harus dilakukan oleh pihak steck holder terkait, baik itu pemerintah daerah dalam hal ini dapat menentukan kawasan-kawasan tertib PKL dan kawasan relokasi secara spesifik, pemerintah kecamatan, dan para anggota satpol PP serta sasaran kebijakan atau PKL itu sendiri dalam hal mensosialisasikan pengaturan PKL. Dimana pada pasal 6 huruf e dan f Perda tata organisasi Satpol PP menyatakan bahwa pentingnya melakukan koordinasi oleh satuan satpol PP dengan pihak pemerintah dan pentingnya pengawasan yang harus dilakukan kepada sasaran kebijakan.

Pemanfaatan Teknologi komunikasi dari stockholder juga merupakan hal yang sangat penting alangkah baiknya apabila
p-ISSN 2302-6960

e-ISSN 2716-165X

pihak terkait dapat memanfaatkan teknologi dengan melakukan pemetaan dan pembagian zona di seluruh kawasan dan jalan yang ada di Kabupaten Sidenreng Rappang. Artinya, apabila teknologi komunikasi ini dimanfaatkan dengan baik dan optimal, tidak menutup kemungkinan komunikasi dapat berjalan dua arah dari masyarakat ke pihak pemerintah dalam mengontrol masalah pengaturan $\mathrm{PKL}$ dan dari pihak pemerintah ke masyarakat. Sehingga dampak negatif dari masalah yang dihasilkan oleh PKL seperti peningkatan sampah, menggagu ketertiban jalan umum dan mengurangi kawasan publik dapat teratasi.

4. Karakteristik Agen Pelaksana

Kejelasan tupoksi dari masing-masing pelaksana masih kurang tegas. Berdasarkan analisis hasil wawancara dapat diketahui bahwa para agen pelaksana yang terlibat dalam Peraturan Daerah Kabupaten Sidenreng Rappang Nomor 8 Tahun 2012 Tentang Penyelenggaraan Ketertiban Umum dan Ketentraman Masyarakat ini sudah cukup tepat dan sesuai dengan karakter serta tujuan dari Peraturan Daerah Kabupaten Sidenreng Rappang Nomor 8 Tahun 2012 Tentang Penyelenggaraan Ketertiban Umum dan Ketentraman Masyarakat.

5. Kondisi Sosial, Ekonomi dan Politik

Dukungan lingkungan sosial dari masyarakat masih kurang. Dalam hal ini permasalahan yang terjadi akibat kurangnya kerjasama masyarakat dengan para pelaksana menyebabkan kesemberautan Pedagang Kaki Lima.

6. Disposisi Implementator

Disposisi adalah watak dan karakteristik yang dimiliki oleh implementor. Apabila implementor memiliki disposisi yang baik, maka implementor tersebut dapat menjalankan kebijakan dengan baik seperti apa yang diinginkan oleh pembuat kebijakan. Sikap dari pelaksana kadangkala menyebabkan masalah apabila sikap atau cara pandangnya berbeda dengan pembuat kebijakan. Pembentukan karakter secara komprehensip melalui kebijakan disposisi yang baikakan mampu menciptakan semangat kerja yang tinggi dan mampu mendongkrak kinerja suatu badan yang dinamis dan lebih maju. Kebijakan disposisi yang baik dan benar memiliki macam-macam pendapat diantaranya benar sesuai 
komitmen atau peraturan yang belaku. Penegakannya sangat bergantung pada kebijakan yang di tempuh oleh unsur pemimpin di khususnya di sini yaitu kepala satuan polisi pamong praja.

Mewujudkan tugas dan fungsi pokoknya, Satuan Polisi Pamong Praja Kabupaten Sidenreng Rappang sudah cukup berupaya optimal. Namun masih ada hambatan yang dihadapi Polisi Pamong Praja dalam melakukan tugas penegakan Peraturan Daerah No. 8 Tahun 2012 tentang Penyelenggaraan Ketertiban Umum dan Ketentraman Masyarakat. Untuk mengatasi hambatan-hambatan tersebut maka Polisi Pamong Praja melakukan berbagai upaya antara lain :

\section{Kelembagaan}

Satuan Polisi Pamong Praja disamping sebagai aparat daerah juga sangat terkait dengan kepentingan pusat sehingga disini kedudukan Polisi Pamong Praja sebagai perekat kesatuan bangsa, karena langkah dibidang ketentraman dan ketertiban tidak bersifat kedaerahan akan tetapi bersifat nasional dengan demikian kepanjangan tanganan lembaga Polisi Pamong Praja mempunyai peran yang strategis di tiap-tiap kecamatan Satuan Polisi Pamong Praja di bawah komando langsung Kantor Polisi Pamong Praja

2. Sumber Daya Manusia

Pengembangan sumber daya manusia Polisi Pamong Praja ke depan seiring dengan berlakunya Undang-undang Nomor 32 Tahun 2004 maka tugas pokok dan fungsi Polisi Pamong Praja semakin luas. Untuk itu perlu didukung oleh personil Polisi Pamong Praja yang kualitas dan kuantitasnya memenuhi kebutuhan dan profesional di bidang tugasnya baik pada saat rekruitment maupun mengirim personil Polisi Pamong Praja secara berkala dalam diklat teknis dan fungsional guna peningkatan ketrampilan serta pengembangan lebih lanjut di bidang keahlian dalam proses penyelesaian perkara. 3. Jaringan Kerja

Guna pencapaian sasaran-sasaran tugas suatu lembaga sangat memerlukan landasan hukum dan kerjasama dengan lembaga-lembaga lain. Begitu juga dengan Polisi Pamong Praja dalam gerak operasionalnya harus didukung oleh peraturan-peraturan yang jelas baik dalam bentuk Keputusan Presiden atau Keputusan Bupati yang dijabarkan dalam Peraturan
p-ISSN 2302-6960

e-ISSN 2716-165X

Daerah, sehingga dalam melaksanakan tugas pokok dan wewenangnya mempunyai landasan yang kuat dan bekerjasama dengan instansi terkait dalam penanganan pelanggaran Peraturan Daerah.

4. Lingkungan yang Belum Kondusif

Keberhasilan tugas suatu lembaga tidak mungkin terwujud tanpa didukung oleh sarana dan prasarana yang memadai sesuai dengan ruang lingkup dan beban tugas. Sehingga di Kantor Polisi Pamong Praja diperlukan kelengkapan kantor, personil dan mobilitas serta anggaran yang memadai agar dalam melaksanakan fungsi dan tugasnya bisa optimal. Untuk penurunan tingkat kesadaran masyarakat terhadap hukum Peraturan Daerah Polisi Pamong Praja memberikan penyuluhan dan bimbingan kepada masyarakat tentang Peraturan Daerah guna terciptanya lingkungan yang kondusif.

\section{KESIMPULAN}

Berdasarkan hasil penelitian yang telah dilakukan, secara umum dapat disimpulkan bahwa :

1. Peraturan Daerah No. 8 Tahun 2012 tentang penyelenggaraan ketertiban umum dan ketentraman masyarakat pada Dinas Satuan Polisi Pamong Praja dan Pemadam Kebakaran Kabupaten Sidenreng Rappang sudah terlasana dengan baik dilihat dari aspek standard an sasaran kebijakan, sumber daya, komunikasi antar organisasi dan penguatan aktivitas, karateristik agen pelaksana, kondisi sosial ekonomi dan politik dan disposisi implementor.

2. Faktor yang menghambat implementasi kebijakan Penegakan Peraturan Daerah No. 8 Tahun 2012 tentang penyelenggaraan ketertiban umum dan ketentraman masyarakat pada Dinas Satuan Polisi Pamong Praja dan Pemadam Kebakaran Kabupaten Sidenreng Rappang antara lain secara kelembagaan, sumber daya manusia, jaringan kerja dan lingkungan yang belum kondusif

Usaha untuk mendorong peningkatan yang lebih baik dalam implementasi kebijakan Penegakan Peraturan Daerah No. 8 Tahun 2012 tentang penyelenggaraan ketertiban umum dan ketentraman masyarakat pada Dinas Satuan Polisi Pamong Praja dan Pemadam Kebakaran 
Kabupaten Sidenreng Rappang penulis menyarankan beberapa upaya sebagai berikut:

1. Penting adanya sosialisasi yang bersifat kontinyu dan rutin tidak hanya diberikan kepada PKL tetapi terhadap masyarakat yang cukup Pro terhadap keberadaan PKL liar.

2. Perlunya peningkatan sumber daya yang telah ada yaitu antara lain jumlah armada yang dimiliki dimana jumlah personil cukup memadai.

3. Perlunya peran pemerintah daerah dalam mengupayakan relokasi tempat berjualan ketempat yang lain yang lebih layak, aman, teratur dan murah sehingga menciptakan suasana yang aman dan nyaman bagi para masyarakat serta pentingnya menjaga koordinasi yang ada.

\section{E. REFERENSI}

Ahmad, Djamaluddin. 2015. Metode Penelitian Administrasi Publik, Teori dan Aplikasi. Penerbit Gava Media : Yogyakarta

Alisjahbana, 2015, Marginalisasi Sektor Informal Perkotaan, ITS Press, Surabaya.

Arikunto, Suharsimi. 2014. Manajemen Penelitian. PT Rineka Cipta, Jakarta

Dwijowijoto, Riant Nugroho, 2015, Kebijakan Publik: Formulasi, Implementasi, dan Evaluasi, PT. Elex Media Komputindo, Jakarta.

Effendi, Tadjuddin Noer, 2017, Pengangguran Terbuka dan Setengah pengangguran di Indonesia Mengapa Tidak Meledak Saat Krisis Ekonomi. Fakultas IImu Sosial dan IImu Politik Universitas Gadjah Mada, Yogyakarta.

Guntur Setiawan, 2013, Implementasi Dalam Birokrasi Pembangunan, Remaja Rosdakarya Offset, Bandung.

Hilal, Syamsul. 2013. Upaya Penataan dan Pembinaan Pedagang Kaki Lima

Joko Widodo, M.S, 2014, Analisis Kebijakan Publik: Konsep dan Aplikasi Analisis Kebijakan Publik, Bayumedia Publishing, Malang. 2008, Model transformasi sosial sector informal: sejarah, teori, dan praksis pedagang kaki lima, Inspire Indonesia, InTrans, Malang.

Nazir, Moh. 2013. Metode Penelitian. Bogor: Ghalia Indonesia

Nugroho Dwijowijoto, Riant. 2015, Kebijakan Publik: Formulasi, Implementasi, dan Evaluasi, PT. Elex Media Komputindio. Jakarta.

Pasolong, Harbani, 2014, Cetakan Kedua, Kepemimpinan Birokrasi, CV. Alfabeta, Bandung.

Sagala, Syaiful, 2014, Konsep dan Makna Pembelajaran, Bandung. Alfabeta, Bandung.

Said Zainal Abidin, 2012, Kebijakan Publik, Penerbit Salemba Humanika, Jakarta.

Samodra, Wibawa dkk, 2016, Evaluasi Kebijakan Publik. Rajagrafindo Persada, Jakarta.

Subarsono, AG. 2010. Analisis Kebijakan Publik. Pustaka Pelajar. Yogyakarta.

Sugiyono.2014. Metode Penelitian Administratif. CV. Alfabeta. Bandung

Sugono, Bambang, 2013, Hukum dan Kebijaksanaan Publik, Sinar Grafika, Jakarta.

Suharto, Edi, 2012, Analisis Kebijakan Publik, Alfabeta, Jakarta.

Syamsu Alam, Andidan Ali, Fareid, 2012, Studi Kebijakan Pemerintah, Refika Aditama, Yogyakarta.

Wahab, Abdul, 2017, Analisis Kebijaksanaan dan Formulasi ke Implementasi, Kebijaksanaan Negara, Bumi Aksara, Jakarta.

Widjajanti Retno, 2018, Karakteristik Aktifitas Pedagang Kaki Lima Pada Kawasan Komersial di Pusat Kota, jurnal Teknik Vol. 30.

Wignjosoebroto, Soetandyo, 2008, Hukum dalam Masyarakat, Bayumedia, Surabaya. 
Dokumen :

Undang-undang Dasar 1945 Pasal 33 tentang Pengertian Perekonomian, Pemanfaatan SDA, dan Prinsip Perekonomian Nasional.

Undang-undang RI Nomor 20 Tahun 2008 tentang Usaha Mikro, Kecil dan Menengah.

Peraturan Presiden Nomor 125 Tahun 2012 tentang Koordinasi Penataan dan Pemberdayaan Pedagang Kaki Lima

Peraturan Daerah No. 8 Tahun 2012 tentang penyelenggaraan ketertiban umum dan ketentraman masyarakat 